\title{
Communication Strategy in Promoting Cultural Tourism Destinations in Semarang City
}

\section{Marhanani Tri Astuti}

Deputi Bidang Pengembangan Industri dan Kelembagaan, Asisten Deputi Industri dan Regulasi Pariwisata, Kementerian Pariwisata Republik Indonesia

\section{Abstract}

The Semarang City Government seeks to raise awareness about Semarang City with a variety of marketing communication programs related to the tourism sector. This paper discusses the various communication strategies used, and the issuance of the decree of the Minister of Tourism Number KM.38 / UM.001 / MP / 2017 concerning the 10 (ten) Branding Logo of Indonesia's Tourism Destinations. The government has set the branding logo for Bali, Bandung, Banyuwangi, Jakarta, Bunaken-Wakatobi-Raja Ampat, Yogyakarta-Solo-Semarang, Lombok, Makasar, Medan, Riau Islands tourism

Corresponding Author: Marhanani Tri Astuti marhanani.triastuti@kemenpar. go.id

Received: Month 2020 Accepted: Month 2020 Published: Month 2020

Publishing services provided by Knowledge E

(c) Marhanani Tri Astuti. This article is distributed under the terms of the Creative Commons Attribution License, which permits unrestricted use and redistribution provided that the original author and source are credited.

Selection and Peer-review under the responsibility of the ICADECS Conference Committee. destinations. At the primary level of communication is an act of government policy (government / regulator) in disseminating and facilitating infrastructure and access to tourism, urban planning, culinary tourism zone policy and public areas. Furthermore, this primary communication the government (in this case the tourism office) has a role as the initiator of city branding and digital marketing. Secondary communication are carried out by stakeholders, in this case business people as enablers, local communities as accelerators, academics as conceivers in the context of city branding. Tertiary communication is related to interactions between layers of society and is strengthened by the media as a catalyst. Tertiary communication uses a forum or media involving stakeholders from the public, private and community dimensions systematically and sustainably, so that it is an implementation that can be realized in promoting culinary tourism destinations in the city of Semarang. The research method uses descriptive qualitative with SWOT analysis. Data collection techniques with interviews. Secondary data were obtained from the official website of the Semarang Regional Government, the official website of the Semarang Regional Tourism Office, the economic growth report from Bank Indonesia, the Semarang Regional Statistics Agency report. The study concludes that local governments metamorphose into balanced local governments that are customer-oriented and accountable to all stakeholders. City branding can be seen as a communication policy, because it is carried out by the government and with regard to public affairs. The communication strategy used by the Semarang City Government more specifically refers to the marketing communication strategy.

Keywords: communication strategy, promotion, travel destinations, culinary..dance, paser tribe, treatment, mulung, magical 


\subsection{Background}

In the era of globalization, one of the interesting phenomena at the moment is that the development of tourism is one of the main pillars of the world economy. The development of global tourism, among others, is driven by advances in telecommunications, information technology and transformation known as revolution $4 \mathrm{~T}$ : Transportation, Telecommunication, Trade and Tourism (Rhenald Kasali: 1998). The development of tourism is an interesting thing is that the increasing welfare of the people, the tendency of tourism to become a part of lifestyle, so that tourism becomes one of the basic needs in addition to clothing and food. (Marhanani Tri Astuti, 2018).

The current global trend shows that culinary tourism contributes greatly to tourism. UN-WTO states that 30\% of tourism income comes from culinary tourism. In 2012 the UN-WTO issued a Global Report On Food Tourism explaining that culinary tourism has an important role to play in developing tourist destinations (Deputy Assistant of Tourism Destination and Industry Development 2015)

In order to attract foreign and domestic tourists to visit Indonesia, one of the government's programs in achieving tourism targets is the creation of 10 (ten) priority tourist destinations or with the term "Creating $10 \mathrm{New}$ Bali" that are scattered throughout Indonesia as in the following picture, namely Lake Toba, Tanjung Lesung, Tanjung Kelayang, Thousand Islands, Borobudur, Lombok Mandalika, Wakatobi, Morotai, BromoTengger-Semeru and Labuan Bajo.

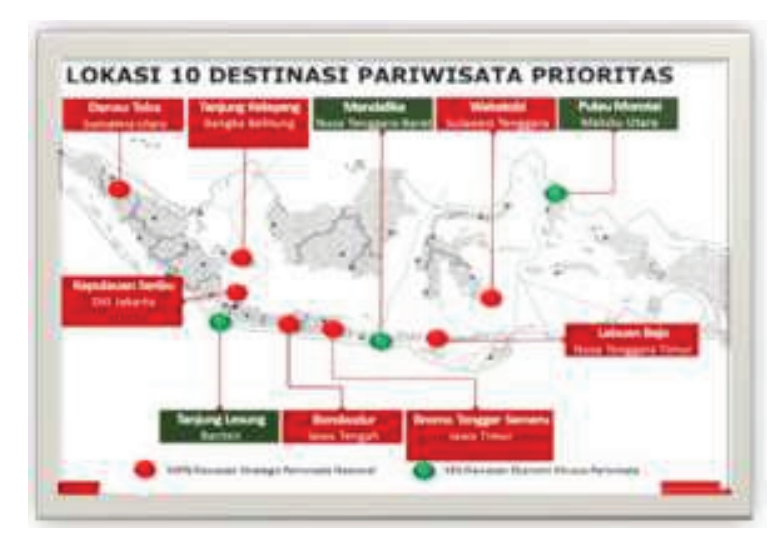

Figure 1: Location 10 Priority Travel Destinations source : Kementerian Pariwisata 2017

In order to improve the marketing of tourism destinations, through the issuance of the Decree of the Minister of Tourism Number KM.38 / UM.001 / MP / 2017 concerning Branding Logos 10 (ten) Indonesian Tourism Destinations. The government sets a 
branding logo on tourism destinations in Bali, Bandung, Banyuwangi, Jakarta, BunakenWakatobi-Raja Ampat, Yogyakarta-Solo-Semarang, Lombok, Makassar, Medan, Riau Islands.

One television program such as Wonderful Indonesia and Indonesian Charm branding fills all print and television media and even social media about Indonesian tourism. More specifically branding against tourism priority destinations. Wonderful Indonesia is branding for international tourism destinations. The charm of Indonesia is branding for local or national tourism destinations (archipelago tourists).

One example of a city branding that is still looking for shapes and models can be found in the city of Joglosemar. Jogja-Solo-Semarang (Joglosemar) destinations are packaged through one brand, Java. According to the marketing deputy of the Ministry of Tourism Prof. Dr. Pitana that "We chose Java because it was able to unite all tourism potential in the Joglosemar region. While the Cultural Wonders tagline is a representation of the strength of tourism in Joglosemar based on cultural tourism. " Regarding the logo image used illustrations from Borobudur Temple which are considered to have existed internationally. (source: http://marketeers.com/ini-makna-di-balik-10-brandingbaru-destinasi-wisata-indonesia)

Positive indicators of global tourism development are reflected in data released by the UN-WTO. If in 1950 the number of international tourists was recorded at 25 million tourists, then in 2014 , that number had increased to 1.087 billion. According to estimates, if growth can be sought at the growth level with an average increase of $6.5 \%$ per year, it is estimated that by 2020, the number of world tourists will reach 1.6 billion people, and by 2030 will reach 1.8 billion.

Positive developments from the tourism sector in Indonesia, foreign tourist visits (tourists) and tourists (winus) who travel in Indonesia show a positive tendency. Foreign tourists visiting the period January - October 2017 reached 11,617,828 foreign tourists or increased by $24 \%$ compared to the same period in 2016 as many as 9,403,614 foreign tourists. The number of wisnus trips in October 2017 also increased by 25,077,000 tourists with expenditures reaching 22.92 trillion while cumulatively from January to October 2017 there were 252,569,465 movements of foreign tourists with expenditures of Rp 230.91 trillion. The achievement of foreign tourists in January - October 2017 is 14\% higher than the target set at 221.5 Million tourists (source: 2017 Tourism Ministry Press Conference).

In addition to the economic impact, tourism also directly or indirectly has an impact on the natural environment and social culture. Good tourism management is able to have a positive impact on the economy, environment, and social culture locally and nationally. 
One indicator of the success of tourism performance is the increasing number of visits / trips made by tourists, both foreign tourists and domestic tourists.

Efforts to increase the number of foreign tourist visits to Indonesia, the government uses one of the communication strategies associated with promotion strategies and social media (internet) through Joglosemar City branding. Branding efforts are carried out to strengthen the image of Indonesian tourism in the minds of tourists, especially in increasing growth and the number of tourist visits according to the target to be achieved.

Destinations create identity as a differentiator from other destinations. Through a brand in a destination, communication between tourists and destinations will be created. Destination brands create a difference with other destinations that can be the foundation for creating a destination's superiority. Communicating a brand is important in creating a destination position to attract tourists to visit a destination (Marhanani Tri Astuti, 2018)

The benefits of communication can only be generated from strong brands (Keller, 2006). Building a strong brand is a priority in the management process (Aaker and Kapferer in Keller, 2009). To build a strong brand requires knowledge of structures that can be accepted by consumers so that a positive response from marketing activities can achieve the expected goals. Marketing communication plays an important role in shaping consumers to understand the marketing program of an organization (Keller, 2006).

The Ministry of Tourism has three programs in culinary diplomacy to improve culinary tourism and introduce Indonesian specialties to foreign tourists, as follows (1) Popularizing national food (2) Polarizing Culinary Destinations (3) Membranding existing restaurants with Indonesia's wonderful branding co (kompas.com)

The culinary industry stretches in Indonesia, data from the Indonesian Economic Agency (Bekraf) noted that the culinary sub-sector contributed 41.4 percent of the total contribution of the creative economy to 422 trillion in 2016, the highest compared to 16 sectors, the subsetor in Bekraf. one of the pillars of the creative industry of 8.2 million creative industrial units, $68 \%$ engaged in the culinary industry (Bekraf RI Research and Education and Development)

The number of foreign tourists visiting Central Java through the entrance of Adisumarmo and Ahmad Yani Airports in May 2018 recorded 1,370 visits, decreased by 32.91\% compared to April 2018 which recorded 2,042 visits. (source: Tourism and Culture Office of Semarang Regency 2018)

Room Occupancy Rate (TPK) of star hotels in Central Java in May 2018 was recorded at $41.81 \%$, decreased by 5.09 points compared to TPK in April 2018 of $46.90 \%$ compared 
to the same period in 2017, TPK in May 2018 decreased by 5.93 points (BPS Prop. Jawa Tengah).

Currently the City of Joglosemar requires branding to increase tourist visits, therefore this study is titled Communication Strategy in Promoting Cultural Tourism Destinations in Semarang City.

Furthermore, not many know if Semarang City also has City Branding. Socialization on this matter is indeed still minimal. The Tabloid Simpang 5 search in the official portal of the Semarang City Government (semarangkota.go.id), about City Branding, is listed in the City Profile of Semarang.

The tagline in City Branding in Semarang City, as contained in the official portal is "Variety of Culture". The explanation is that Semarang is different from other cities in Indonesia. Semarang City has Cultural Diversity and it is the main asset that is highlighted, because from a tourist point of view it is an attraction for them to visit the City of Semarang.

The impact of this diversity of cultures is sure to bring up many types of variations in many ways. For example, seen from the point of view of art, heritage / architecture, religions, culinary and other events. From culture, it can also be seen that the culture in Semarang City includes Javanese, Coastal, Arabic and Chinese cultures. One element in cultural tourism is culinary tourism.

"Variety of Culture" means that the city beautifies itself and develops while maintaining its heterogeneous culture. The message was conveyed that a touch of harmonization of various Javanese cultures along with Chinese, Arabic, and Dutch cultures is still felt in Semarang City. (http://tabloidsimpang5.com/mengenal-'city-branding-kota-semarang/)'

In order to improve tourism promotion, among others through branding, the local government made an effort by making a study of Communication Strategies in Promoting Cultural Tourism Destinations in the City of Semarang with the aim that the branding can be known and is a tourism promotion tool of Semarang City.

Semarang City Government needs to think of city branding to sell tourism potential. Semarang, according to him, has excellent tourism objects, both coastal and natural, such as in Kandri Tourism Village, Gunungpati District. "But there is no city branding, so tourism activists find it difficult to sell both in the real world and cyberspace so when looking for tours in cyberspace, Semarang still loses from Yogya or Bali," (@wisatasemarang account) to the Central Java Tribune, some time ago.

Furthermore, the city government needs to move to promote tourism through cyberspace amid the rapid development of internet technology. "The City Government 
needs to be aware of technology so that Semarang tourism is known throughout the world," (http://tabloidsimpang5.com/engenal-city-branding-kota-semarang)

The problem in this study is how to communicate strategies in promoting cultural tourism destinations in the city of Semarang. The Communication Strategy promoted by the government includes: the branding (branding) program and policy that was intensely promoted in Semarang City, became a challenge in making the promotion strategy of Semarang City through Semarang branding as a Culinary tourism destination. The potential that has been owned by the area becomes futile if it is not balanced by an effective strategy. Currently destination branding, especially those related to tourism destination branding, is a common approach for promoting tourist destinations and becoming a trend among marketers of tourist destinations.

The strategy carried out by the Semarang Regional Government is an activity known as City Branding. City branding is a rapidly developing strategy in various countries or cities to make a strong positioning in the minds of their target markets, such as products or services According to marketing expert Hermawan Kartajaya (2005: 60), currently city branding is indeed a must do every city who wants to elevate his degree.

Regarding the communication strategy through strengthening Semarang city branding, the purpose of this study is:

1. To find out, explain, and analyze Semarang how the government communication strategy in the city of Semarang in order to promote the image of cultural tourism destinations in this case culinary tourism with city branding programs.

2. To find out, explain, and analyze the city branding process so that the city of Semarang has the image of a strong Culinary tourist destination.

3. To find out, explain, and analyze the strategic communication plan of the City of Semarang in promoting culinary tourism in the city of Semarang by forming city branding.

Branding is one form of communication that requires similarity of meaning as an end result. Branding actors hope that the community can then have an impression of themselves, products, companies that are imaged as expected. Branding is closely related to the physical dimension, which is where it is located. Someone will portray themselves differently when in a different place. Branding is also closely related to the social dimension of psychology, namely the environment of psychological relationships between communicators and communicants. 
At this level, it appears that branding is not a simple process. Therefore, in this study will describe the communication strategy through branding from the ontological, epistemological, and axiological aspects which are the three most basic aspects of conducting philosophical studies of branding as a communication activity.

Ontology discusses what you want to know, the nature of what you study (Karimah and Wahyudin, 2010: 20). An ontological review is an attempt to provide an answer to the "what" question. Aristotle called the question as the first philosophy and is the science of the essence of things (Bakhtiar, 2004: 219).

Jefkins (1994: 30) describes the image into five categories, namely image image (mirror image), current image (current image), expected image (wish image), corporate image (corporate image), and compound image (multiple image).

Basically, every person or company, organization, wants an image that matches their expectations. Therefore, they will try to direct the other four types of images (mirror image, current image, corporate image, or multiple image) to meet expectations, by making branding. Thus ontologically branding is an effort made by a person or company to make other parties can have an impression about themselves or a company or organization, to make other parties can have an impression of themselves or their company or organization as expected. Therefore branding can also be said as an image formation activity or image building activity so that other people can give a positive impression on themselves and the company.

From an epistemological side, understanding of branding depends on the amount of information that is owned or the experience that is possessed of something. So that branding lies in the cognitive process, how to make the public understand about the company, the organization as expected.

At the level of axiology, which is related to the way in which science has been used epistemologically before, branding needs to be seen in the aspect of value. Similarly, the value attached to branding. What is the value of branding for us? To get answers to these axiological questions, it is necessary to look at the previous ontological and epistemological conclusions. Ontologically branding is a process of forming or directing a public impression (image) about self or company / organization in accordance with what we expect. Epistemologically branding is done by building a good understanding of the public through providing complete information about the object being imaged. And axiologically branding is the process of meaning (value creative) of the value revealed in the symbols and images that are being branding. 


\section{Discussion}

Simon Anholt (2007) also defines city branding from the side of communication science especially as a function of public relations by interpreting city branding as management of a destination's image through strategic innovation and economic, commercial, social, cultural and government regulations. This understanding is reinforced by another opinion suggested by Kavaratzis $(2008$, h.8) which reveals that city branding generally focuses on image management, precisely what and how the image is formed and the aspects of communication carried out in the process of image management. City Branding is also the task and collaboration of all stakeholders (Stakeholders) associated with the city. The responsibility for the success of city branding is found throughout the city's internal public, both city government, private sector, business people, the Interest Group and the city community. In city branding, what is prioritized is by functioning of all the city's potential to be valuable and functional. The City Branding concept is then directly proportional to one aspect of development in an area. Because it is one of the development programs, the government needs to communicate the benefits or uses of each development in its area to the community. The government in conveying the messages of development needs to have credibility, attractiveness, hopes and feelings so that people can be influenced to follow the wishes of the government so that development can be carried out.

The paradigm underlying the emergence of the phenomenon of city branding is the existence of constructivist thinking. Constructivism is an approach that can be used in communication science studies. This constructivism puts pressure on the impact of individual differences that remain in the processes of social perception of the development of communication behavior. Besides that, it also uses human-centered communication behavior. This paradigm has a purpose to carry out reconstruction of understanding. Knowledge gained is in the form of reconstruction of individual thoughts that are integrated with their social environment.

Constructivist thinking occurs due to interactions that occur between researchers and systems or subject of study which in this case is a city that includes government, society and its environment, also reinforced by how the messages raised to bring a goal in the form of a vision or current mission We emphasize the establishment of city branding in a city. The message-making strategy carried out by communicators is inseparable from the message production theory. Where in Littlejohn (2008) explains the element of making messages there needs to be traits, behavior, and cognitive. Traits contain several important things that are observed, namely conversational narcissism, 
argumentativeness, and social/ communication anxienty. While the behavior includes overactive behavoural inhibition system, accommodation power, and adverse stimulus (interaction / adaptation). And cognitive discusses various thoughts in the production of the message itself such as message design (FTA = face-threatening acts), action assembly, planning, Kelly's constructivism personal construct theory and logic message design.

City branding as a communication message will be explored based on traits, behavior and cognitive where the communicator as a message maker needs to be able to make a good city branding message to be accepted by the community. And that process will later be part of this study. In writing this book, researchers will study Semarang City branding more from the point of view of Communicators namely Semarang City Government Semarang City Culture and Tourism Office (as the implementer of Semarang City city branding policy in the tourism sector) as a city branding maker and messenger.

One of the difficulties in building a city image is determining the target audience and stakeholder groups. The focus of the theoretical framework in Kavaratzis (2004:60) is for urban residents. This is emphasized in facts for all activities (whether economic, cultural, social, tourism, and various other urban developments) carried out by city residents and their main goal is to improve their quality of life. This theory is described as follows;

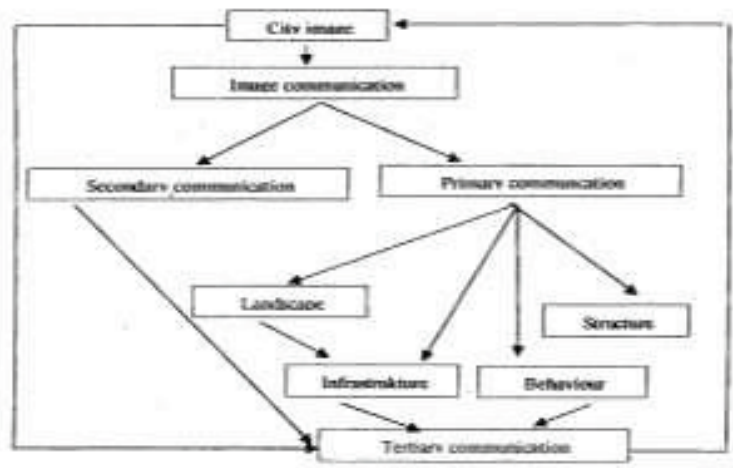

Figure 2: Komunikasi Merek Kota Source: Kavaratzis (2004)

Factually bringing together the interests of all stakeholders of a city is the perception and image of the location. This is accepted because the city image needed needs to be planned and is a consequence of city promotion (Vermeulen, 2002: 60). External and internal interactions become the main points for the image of the city.

A city in all things needs to be done consistently, all city messages are related to the city image through a type of communication that is divided into three parts; primary communication, secondary communication and tertiary communication.

\section{Primary Communication}


Primary communication is the effect of communicative relationships on an action taken by the city. This action can be seen in the first landscape strategy, relating to actions in the fields of action and decisions that are appropriate for urban design, architecture, green zones, and public areas in the city.

Organizational structure and administration are related to the success and progress of the structure of city governance In this case the community development network and population participation in making decisions that further build community relations. The last part is "behavior" owned by the city. This relates to issues such as the leader's vision for the city, strategies adopted or the provision of financial incentives by the city to various stakeholders. There are two significant elements to this, namely the type of service carried out by the city along with their success in determining and the number of various events or attractions carried out around the festival, culture, sports, etc. held by the city. Based on the decision of the Minister of Tourism Number KM.38 / UM.001 / MP / 2017 concerning Branding Logos 10 (ten) Indonesian Tourism Destinations. So the Government sets a branding logo for Bali tourism destinations, Bandung, Banyuwangi, Jakarta, Bunaken - Wakatobi - Raja Ampat, Yogyakarta - SoloSemarang, Lombok, Makassar, Medan, Riau Islands In order to increase the marketing value of Indonesian tourism destinations.

\section{Secondary Communication}

Secondary communication is communication carried out by the government to make policies that are referred to by stake holders. Government communication is supported by budget policies that can help the program. Examples of desimination programs, indoor and outdoor advertising, public relations, graphic design, use of logos.

This is necessary in city marketing communication, because it is one of the factors for urban marketing to succeed.

\section{Tertiary communication}

Tertiary communication is related to the level of society where they also promote Culinary tourism destinations as Semarang city branding. The direct line from primary communication to city image shows that there are parts that cannot be controlled. Overall the process of city branding and there are two things that can be controlled to build an image that is building communication objectives to generate and strengthen positive tertiary communication, especially also in the case of city residents, where they at the same time become the target audience and city promotion.

The communication relationship on primary, secondary and tertiary communication related to city branding is clearly described by Kavaratzis 2004 as follows: 


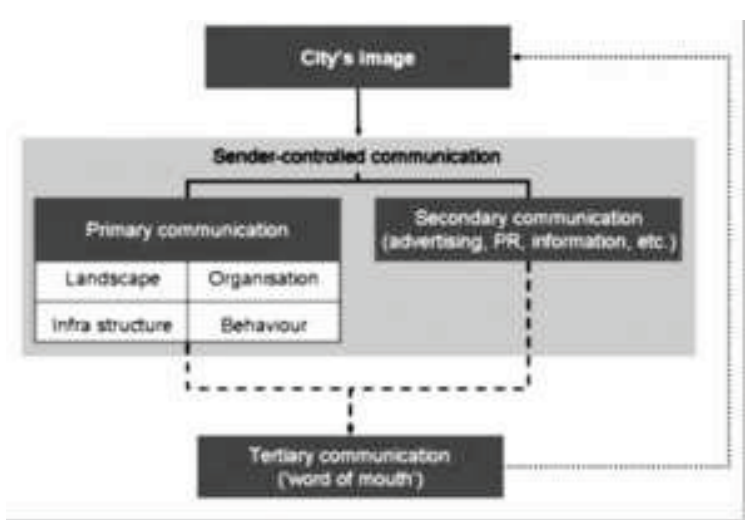

Figure 3: Relation of communication in primary, secondary and tertiary communication, source : Kavaratzis $: 2004$

Based on the picture above, the success of city branding can be seen from city image, which is formed based on tertiary communication (word of mouth) after the implementation of primary communication by the city government and campaigns through Public Relations and advertising by communication consultants in the secnder communication framework.

According to Litlejohn (2008: 70), communicators do not only interact with others through social objects, but also communicate with them. Communicators run self conversations as part of the interaction process. When making choices about how to act on social objects, communicators create what is called an action plan, which is then guided by an attitude or verbal statement that indicates the value at which the action will be directed.

The current development of globalization has implications for the image or reputation of a country that has resulted in competition for identity to maintain the existence of a country and efforts to gain attention and influence (Anholt, 2009: 20), now information flows so quickly that events occur in a region or country in just seconds can spread so fast

Identity is also a cultural power. Various studies have found that the power of identity, such as the rise of social change in the community, is usually based on things around identity such as gender, religion, ethnicity, nationality. This identity competition is also driven by a logical combination between capitalist development and the speed of development of decentralized media in a region and communication technology (Tomlinson, 2003: 105). The results of the Inn, Kim study (2004: 233-240) in South Korea that this cultural identity is the basis for building an area where marketing strategies play a role.

Globalization makes the world like a busy market. This is an important part because it means that every country, city and region needs to compete with each other to 
share transactions in the commercial, political, social and cultural world. So, now image becomes one of the important factors as a way of providing information to the market in influencing the decision to transact. So, the image and identity of a country, city or region is a valuable asset in today's modern world.

Some countries, cities or regions are fortunate enough to have a positive image or identity, but some actually have a negative image or identity. Most of these images or identities come from public opinion not from marketing experts or the government.

\subsection{Integrated Marketing Communication (IMC)}

Globalization has given birth to a number of concepts, new ways of thinking and strategies in marketing, this is influenced by the rapid development of information technology This condition places marketers in an intersection between two paradigms that attract each other, namely the business industry era and business information era. Some of these differences are described by Kennedy and Soemanagara (2006: p. 11) in the following table:

TABLE 1: DIFFERENCES IN THE ERA OF BUSINESS AND ERA BUSINESS INFORMATION INDUSTRY

\begin{tabular}{|c|l|}
\hline \multicolumn{1}{|c|}{$\begin{array}{c}\text { BUSINESS INDUSTRY } \\
\text { ERA }\end{array}$} & $\begin{array}{c}\text { BUSINESS INFORMATION } \\
\text { ERA }\end{array}$ \\
\hline $\begin{array}{c}\text { 1. Consumers with small } \\
\text { amounts are easy to reach } \\
\text { and easy to reach }\end{array}$ & $\begin{array}{l}\text { 1. The consumer is broad, but } \\
\text { cannot be seen (invisible) }\end{array}$ \\
\hline $\begin{array}{l}\text { 2. Products are created to } \\
\text { meet market needs }\end{array}$ & $\begin{array}{l}\text { 2. Products are created not } \\
\text { only to meet the needs but } \\
\text { also to obtain customer } \\
\text { satisfaction. }\end{array}$ \\
\hline $\begin{array}{l}\text { 3. Business organizations } \\
\text { have a large size with the } \\
\text { number of employees in } \\
\text { thousands. }\end{array}$ & $\begin{array}{l}\text { 3. Business products are } \\
\text { increasingly small, but } \\
\text { complex and with high } \\
\text { human resource capabilities }\end{array}$ \\
\hline $\begin{array}{l}\text { 4. The traditional business } \\
\text { concept is strong, namely } \\
\text { "reducing costs (efficiency) } \\
\text { to get big profits. }\end{array}$ & $\begin{array}{l}\text { 4. Capital is mobilized to } \\
\text { achieve an effort in placing } \\
\text { the company in an important } \\
\text { position in the market }\end{array}$ \\
\hline
\end{tabular}

By looking at the table above, the comparison is different, and in the current period the concept of the business industry era still has an important role, especially in developing 
countries such as Indonesia, while the concept of the business information age is now developing in several developed countries.

This information age has revolutionized the old economic activities in the world. The development of communication technology and the ease of access has made communication an important part of marketing and a determinant of marketing, through primary, secondary and tertiary communication. All organizations, both business and non-profit use various forms of marketing communication to promote what they offer to achieve financial or non-financial goals. The development ofdigital technology that has cross-border multimedia and internet capabilities has changed the face of this increasingly complex civilization. This development not only changed the rules of business play, but also marketing (Estawara 2008: 25).

Responding to changes in the modern business environment that are full of uncertainty, the marketing discipline then responds quickly. According to Schultz in his article entitled "A Multi-Country Comparison of Drive for IMC" in Estawara (2008: 30), digitalization, information technology, intellectual property, and communication systems are the main entities that encourage discussion of the concept of marketing communication. Marketing communication is a collection of parts for various ways that are planned to convey messages used to build images such as advertising, public relations, sales promotion, direct sales, packaging, events, sponsorship, and customer service. Media is a means to bring marketing communication messages to the target audience (Duncan: 2005: 19)

The emergence of various communication, messaging and audience tools makes the company conduct a Marketing Communication Mix or Integrated Marketing Communication (IMC). IMC was originally based on marketing communications and from this point the IMC was built. If seen from the point of view of marketing communication which is often only understood technically as a promotion mix (Estaswara, 2008). Promotion mix has four elements called 4P (product, price, place \& promotion). Marketing communication programs usually combine these four elements (Morissan, 2007: 20). Schultz (2003: 70) defines IMC as a marketing communication planning concept that shows added value from a comprehensive plan that evaluates the strategic role of various communication disciplines, such as general advertising, direct response, sales promotion, and public relations and combines various disciplines this is to create a clear, consistent and maximum impact of communication

Some marketing experts also try to define an IMC such as Braun. E (2008: 60) in Coopley (2004: 70) is a way of thinking, spirit unity (a single theme to support a brand or image, an intellectual message that is simply one voice, one appearance and not 
complicated), synergy (the uniqueness of the message which reinforces each other), one strategy (a single communication strategy that includes what is needed to achieve the goal), the same status of each element of communication which will be dominated by advertisements combined with various sciences such as advertising and public relations or direct sales with promotions), stakeholders' attention and marketing orientation.

While according to Shimp (2000: 40), IMC is the process of developing and implementing various forms of persuasive communication programs to customers and prospective customers on an ongoing basis, which aims to influence and provide direct influence on the behavior of the target audience. IMC considers all sources that can connect customers or prospective customers with products or services of an image or company is a potential pathway to deliver messages in the future. The IMC process starts from consumers and then turns to the company to define the forms and methods that need to be developed for persuasive communication programs..

The above definition illustrates that IMC is not just promotional mix. Although generally IMC is built on four marketing elements. IMC offers promotions through ways that are not only through advertising. IMC is a concerted effort to make all marketing and promotional activities of companies able to produce images or images that are consistent for consumers (Morris, 2007: 20). IMC is also about how to manage relationships with customers or prospective customers day by day. Because business is a continuous process, so is communicating images. There will always be customers or prospective customers who ask, complain, and give input which needs to be heard and given a response every time. Now building relationships and brands is not just giving messages to customers or prospective customers. So IMC is like a continuous circle of communication processes (Duncan, 2005: 19).

This marketing communication process as described by Duncan (2005: 107) in the picture below the Company as the source or sender and also called the initiator of the message. In the basic model of communication this is called encoding which is the process of making a message. Then the message is made in the form of a combination of words, images, symbolic actions and events. This combination of messages is delivered through media such as TV, radio, newspapers, magazines, internet and telephone. In the process of communication starting from sending the message until the message is received by the customer, the thing that needs to be considered by the company / organization is interference or noise. Customers or customers and stakeholders will receive a message that will then provide feedback by responding to the message they received. 


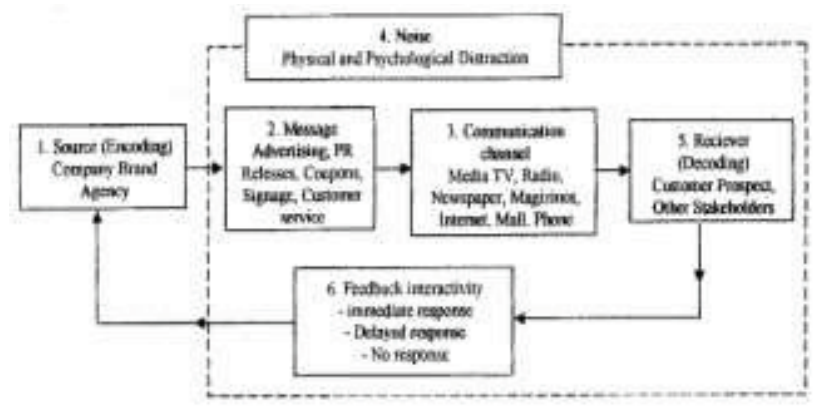

Figure 4: Marketing Communication Process Source: Duncan (2005:107)

\subsection{Branding}

Branding is not a new phenomenon. Since ancient times symbolic and ornamental images have been used as tribal or national symbols to express power and power, by kings, emperors and governments to declare ownership or control. Then, the last 30 years the use of imagery has grown from identity to livestock to sophisticated companies. Information technology such as television is heavily involved in this, as is the rapid growth of secondary industries and service industries (Knapp, 2001: 50).

Branding is a process of designing, planning and communicating names and identities in this case to build or manage reputation (Anholt, 2009: 80). Building a successful image is not easy. Building an image involves four logical steps (Kotler, 2005: 70), namely setting the appropriate image identity (building a deep and broad image awareness), creating the appropriate image meaning (unique image association), generating the right image response (positive reaction and acceptable) and forming a decent relationship with customers (strong and active loyalty). David Aaker (1991: 50) in Knapp (2001: 123), there are five conditions that need to be fulfilled in building an image that is perceived quality, awareness of image names, image associations, image loyalty and other ownership assets.

Awareness describes the existence of images in the minds of consumers, which can be determinants in several categories and usually have a key role in image equity. Image awareness pyramid from the lowest to the highest level (Durianto et al., 2004: 40).

\subsection{City Marketing Mix}

Marketing facilitates the exchange and development of consumer relations. In general this process is called the marketing mix (marketing mix) consisting of $4 \mathrm{P}$, namely product, price, place (distribution), and promotion. The basic task of marketers is to combine these four in a balanced combination of strategies. Marketing managers have long realized 
the importance of combining various elements of the marketing mix into a round and intact marketing strategy (Morissan, 2007: 20). This also in fact has become part of the context of city marketing to answer several problems, where specifically cities or regions are associated as marketable assets and their relation to elements in the marketing mix to urban marketing (Kavaratiz: 2004).

Kotler, 2005: 70, said that despite adopting a marketing mix in general, there were differences in strategies for marketing cities or regions. The strategy can be seen through Design, which is a place that has character or uniqueness such as urban planning that is made in such a way as to attract tourists, infrastructure, namely a place as a regular environment and the availability of public facilities in the city. Basic services are the availability of places to serve the community. Attraction is the availability of a place that is a center of entertainment and recreation.

The implementation of city marketing can be successful if the city government continues to identify and improve the city's image. Things that can be done to achieve goals, should follow several policies in some of these fields, namely; advertising and promotion, large-scale physical development, large-scale events to attract world attention, cultural regeneration, public-private partnerships.

The image or identity of the city is usually formed based on various resources such as history, culture, customs, industry, landscape, environment and many others. City marketing in reconstructing the image of the city has been restricted only to place promotions by simple advertising just to inform resources (Inn, 2004: 233-240).

In some cases Kota has a Culinary tourism brand attribute is the main thing to express the image in the regional marketing process, Culinary Tourism is a form of contemporary tourism carried out by individuals who buy goods and services outside their usual environment as a determining factor in their decision to travelling. (UN-WTO: 2013)

Understanding the culture and purpose of branding and hope for the location of the city as the heart of the city's marketing. Building an image makes a product more specific and has a different identity (Cova, 1995: 45) and this is applied in various ways for city marketing. The image provides information about a city that is easier to understand and the characteristics of a place are known. The city image provides a basis for identifying and bringing distance to the audience in understanding a city by giving city attributes in the form of a marketing message, which is often called the image of the city. (Kavaratzis, 2004: 58-73) 


\subsection{City Brand}

Globalization provides an opportunity to compete for all cities in the world, both newly established and established, the reason is simple, now people can live and work anywhere now. In recent years there have been changes in human behavior in determining where to live, work or tourism. Some people expect a better quality of life, can live comfortably and safely. As a result of this reaction, various city governments in the world are improving themselves from cities that traditionally change themselves by providing various restaurant facilities, hotels, education, sports events, seminars, conferences and art and cultural attractions. These activities are basically the way the city communicates itself or in marketing is a way to reach the target market (Marhanani Tri Astuti, 2018.

Tourism is also an important part of the goal of building a city image. According to the World Tourism Organization (WTO) in the 1990s tourist travel averaged 4.3\% each year and in the $2000 \mathrm{~s}$ it increased to $7.4 \%$. In addition, travel and tourism encourage both directly and indirectly making $11.7 \%$ of GDP (Gross Domestic Product) globally and close to 200 million jobs. In 2020 international tourists are expected to reach 1.6 billion, with gross revenues of more than US $\$ 2$ trillion. This is the big news for every city where Tourists make jobs in hotels, restaurants, consultants, transportation, training, and help various businesses around them (Winffield, 2005: 40).

At least the literature on the image of the city makes a concept and its application is ineffective or misunderstood. Therefore understanding the city as an image and how to apply it is important to understand. By following the definition of the image can help to understand it The image of a product or service is made specifically with positioning related to competition and having a personality functions as attributes and values (Hankinson \& Cowking, 1995: 43-50). Like the image of products and services, the city also functions to fulfill symbolic and emotional needs and attributes to meet the needs of the public such as an orchestra in conveying the uniqueness of the city (Asworth \& Voogd, 1990: 50). The image provides a good start for city marketing (Kotler 2005: 170) and a framework needed to regulate the city image If indeed the city image needed to be planned, arranged and sold then the city's image will become a true and approaching theory (Vermeulen, 2002: 160).

\subsection{City Branding Process}

The process of building a city image consists of several stages (CEOs for Cities, 2006)

1. Determine clear goals 
This is commonly done by practitioners. And relating to the identity of the city, what needs to be determined is the purpose of establishing the image of the city whether to attract tourists, investment or for other purposes. This step is needed so that it can be evaluated properly.

2. Understand or recognize the target audience

Identifying the target audience is not just a challenge to describe how to reach them by conducting a study.

3. Identify the latest image

The main objective of this step is to recognize whether what exists is in people's perceptions of the city at this time.

4. Create an inspiring image image identity

An inspiring image identity is something we expect the target audience to think about that community.

5. Determine positioning

Like other products the positioning of a place needs to have credibility, drive, difference and support Positioning.

6. Plan the value carried

It is an act of how to treat the target audience to fit the promises that have been offered.

7. Establish branding strategies

It is part of the process of city branding, relating to the target audience is an element needed in the city branding strategy. Therefore, every opportunity to interact with the target audience should be utilized as well as an opportunity to promote the city. brochures, websites, events, media and even the attitude of the population.

\section{Measuring success}

Is the most important part of the branding strategy. Because this matter can find out the goals that have been achieved and the suitability of planning and objectives. Here are some things that can help to measure the success of an image through a) Brand Awareness (Image Awareness) b) Brand Recognition c) Brand Understanding d) Brand Delivery, e) Brand Value Brand Preference f) Brand Uniqueness (Uniqueness of the Image). 


\subsection{Culinary tour}

According to WTO (2004) Culinary phenomena are part of human activities, which include their behavior, life style, purchasing power capacity, the consumption environment faced in everyday life. While Morison (2007) describes Culinary tourism as an activity and motive for traveling in the form of culinary activities of goods and services outside the daily residence to create memories and experiences during the tour.

Tourism can be classified according to the main purpose, one of which is "Culinary" from the perspective of demand, namely visitors traveling with culinary purposes (UNWTO 'Global Report on Shopping Tourism 2013). Currently, countries that develop culinary tourism and shopping are France, America, Spain, Italy, Turkey, Germany, Russia, Malaysia, China and Singapore.

The benefits of developing Culinary tourism and shopping, are as world-traded / global services, this sector provides 1 out of every 11 jobs and for many developing countries is one of the main sources of foreign exchange income, creating jobs and opportunities to develop development (UNWTO: 2013).

Today millions of tourists carry out culinary activities which are their main goals, or one of their motivations for traveling. The Culinary area destination is a tourism destination that can be known as Culinary tourism.

\subsection{Semarang City Study Locus}

\section{Economy}

The economy of Semarang City is quite large because of its status as the provincial capital of Central Java. The economy of Semarang City according to the 2012 BPS data is dominated by the Industrial sector and the Trade sector [8]: 43; 2012 GDP (Gross Regional Domestic Product) based on current prices reaches Rp. 54.38 Trillion [8]: 38-39 High economic growth is characterized by the number of tall buildings in the form of hotels, offices and apartments in Semarang City; The list of the tallest buildings in Semarang shows that Semarang City has 30 buildings with a height of at least 12 floors and 75 buildings with elevations ranging from 7-11 floors.

Integrated Business Area - Central Business Districts (CBD)

As the provincial capital of Central Java and the fifth largest metropolitan city in the territory of the Republic of Indonesia, Semarang has transformed and changed dynamically towards a better direction. In less than 10 years, Metropolitan 
Semarang continued to build a vital financial contribution in Indonesia due to its growing trade and industry sectors and services. As a consequence, people's purchasing power increased, capital inflows, consumer confidence index and doing business were relatively conducive to developing several CBDs (Central Business District). Some CBDs included in the golden triangle prime area, among others.

Simpang Lima Ciy Center (SLCC) is one of the Central Business Districts (CBD) located in Semarang Center and one of the developing CBDs in the heart of Semarang. No wonder that many tall buildings or commonly called skyscrapers are present in this area. Some signature buildings that are characteristic of SLCC Semarang are Ciputa Swiss-Belhotel International Hotel Semarang, Ciputra Mall, Horison Hotel, Plaza Simpang Lima, Louis Kienne Serviced Apartment Hotels, HAKA Hotels (coming soon), Santika Premiere Hotel, Wisma HSBC, INDOSAT Oooredoo Tower, Living Plaza ACE Hardware \& InForma, Gramedia Pandanaran Center, Accor Ibis Simpang Lima Hotel, Amaris Simpang Lima Hotel, Tentrem Hotel Mall Apartment Semarang (coming soon), Simpang Lima Residences, SMC (Semarang Medical Centerl) Telogorejo Hospital, Pandanaran Hotel, DBS Center, @Hom Hotel, SentraLand Superblock, Graha Bank Indonesia, Plaza Telkom, Telkomsel Staff, XL Axiata Center Simpang Lima, Bank Mandiri Plaza, CitiBank Square, Scout Building,

\section{Population}

The population of Semarang is generally Javanese and uses Javanese as an everyday language. The majority religion adopted is Islam. Semarang has a large Chinese community. As in other areas in Java, especially in Central Java, they have been closely mingled with local residents and used Javanese in communicating for hundreds of years.

\section{Nickname}

The city of Semarang has several nicknames, including: Venetië van Java, Lumpia City, ATLAS City (Safe, Orderly, Smooth, Beautiful and Healthy) and The Port of Java. Semarang Enchantment of Asia

In 2009 from the discourse of several parties, the Mayor of Semarang agreed to the slogan "SPA", where the consequence was that cleaning and development were carried out everywhere (repairing channels, roads, sidewalks, parks, arrangement of roads).

\section{Pariwisata}


(a) Kuliner

Indonesia has a great opportunity in making culinary tourism an attraction for foreign tourists to visit Indonesia.

The global trend of culinary tourism in the future will tend to be a search for local heritage-based culinary experiences. Food and drinks but become a cultural experience for tourists (an element of memories in Sapta Charms).

Spices (spices, tamarind sugar or spicy symbols of food taste) will provide a taste experience that is always remembered by tourists so that it becomes a memory of Indonesia (Deputy Assistant of Deputy Development of Cultural Tourism Destinations, 2017 Ministry of Tourism)

As an archipelagic country covering 17 thousand islands and 1340 ethnicities and 700 local languages make Indonesia a great opportunity to offer a unique and authentic variety of culinary culture experiences, not found in other countries.

It is estimated that Indonesia has 5300 traditional foods that can become capital in developing tourism destinations where traditional food is very potential to be a fundamental component of a destination attribute to enrich the attractiveness and experience of traveling in Indonesia.

When Indonesian cuisine is in demand and enjoyed by foreign tourists, it is certain that culinary tourism will have a positive impact on the local economy. This is in line with the motto of the Ministry of Tourism, which is increasingly conserved, increasing the welfare of society.

Preserving Indonesian cuisine is an effort to build the welfare of the Indonesian people.

Likewise with dishes that are in the city of Semarang. Therefore, an effort is needed to promote and strengthen the identity of the culinary tourism destinations in Semarang with branding.

- Cook

Semarang's special foods include:

Bandeng presto, Soto Bangkong "Soto Semarang", Mie Kopyok, Sega Becak, Sega Lunyu, Sega Ayam, Tahu Pong, Pecel Koyor, Petis Kangkung, Tahu Petis, Tahu Gimbal, Bakso, Babat Gongso

- Snacks

Lunpia Semarang, Spekoek, Jongkong Singkong, Gandos, Kue Moci, Blanggem, Timus, Gilo-gilo, Tahu Gimbal

- Drink 
Semarang specialty drinks include:

Kolak Setup, Es Cao, Es Marem, Es Congklik, Es Dawet Durian Kampung Kali, Es Krim Toko Oen, Wedang Durian, Wedang Jahe Rempah, Wedang Lengkeng, Wedang tahu, Wedang Jalang,(Wedang Jahe Alang-alang), Wedang Kacang Tanah

- Oleh-oleh

Lumpia, Roti Gandjel Rel, Jambu Semarang, Wingko Babat, Mari Wijen, Bandeng presto

A variety of cultures that exist in the city of Semarang can attract tourists both domestic and foreign tourists.

One of the cultural attractions is culinary. Therefore the authors are interested in strengthening the branding of Semarang City as a culinary tourist destination. Furthermore, the regional government of Semarang City can promote tourist attraction, among others, by creating (strengthening branding) Semaang City as a culinary tourism destination.

\subsection{Potential Identification and Development Policy of Culinary Tourism in Semarang Region}

\section{Situation Strategy Analysis (SSA)}

"I set tourism as the leading sector. Tourism is used as the leading sector, this is good news and all ministries are obliged to support it and I set it up "(Indonesian President Joko Widodo)

Comparison of growth of Indonesian tourists with regional \& global markets namely Indonesia collapsed 22\%, ASEAN grew 7\% and the World grew 7\% from January to December 2017.

Indonesia increases 22\%, Vietnam 29\%, Malaysia 4\%, Singapore 5.8\% and Thailand 8.7\% (source: Menpar Exposure 23 Mar 2018 from Statistics of each countries).

Creative Economy Construction on Indonesia's GDP in 2017, Culinary $41.69 \%$ and Shopping 33.85\% (source: BPS and Bekraf 2017).

Distribution of foreign tourists' expenditure to Indonesia in 2016 includes: Tourist Expenditures for Culinary and Shopping is 30\% of Total Spending.

In 2017, foreign exchange in the tourism sector was recorded at Rp.182 trillion and the contribution of culinary tourism was Rp.54.6 trillion. 
Targets in 2018, Tourism contributes foreign exchange of Rp. 223 Trillion and Culinary Tourism and Rp. 66.9 trillion.

The general target of culinary tourists includes:

Culinary tours $42 \%, 1,785,000$ and shopping tours 58\%, 2,465,000 (2018). Likewise, the target of culinary tourists and shopping in 2019 is covering 6,000,000 including: 42\% Culinary Tourism, 2,268,000, 58\% shopping tourism, 3,132,000. In general the challenges of regional tourism include: Structuring, Buildings, piles of useless items. Sanitation, food stalls, cleanliness and hygiene (using gloves)

\section{Strategic Formulation (SF)}

According to UN-WTO (World Tourism Organization), culinary Tourism (Gastronomy) is the experience of traveling to a gastronomic area, for recreation or entertainment; which includes visits to primary \& secondary food producers, festivals and exhibitions, farmers and markets, cooking and demonstration events, tasting quality food products, and other tourism activities related to food.

Tourism activities related to food and beverages in order to increase knowledge and experience of travel, strengthen / strengthen social relations, and express lifestyle. (source: Global Gastronomic Report).

Culinary benchmarking (gastronomic) is Vietnam including Cullinary namely: (1) Pho (2) Cha ca (3) Bawit.

3. Implementation Strategy (SI)

In the implementation in Vietnam applying the 3B strategy concept includes:

1. Branding is a product that is ready and ready for sale. Next time.

2. Boosting: potential and access to facilities already exists but the industry is not ready

3. Builgeng: The potential already exists but the products are not ready for sale (Human Resources, society and industry). (source: Culinary Potential Manuscript; Asdep Cultural Tourism Destinations Deputy for Destination Development and Tourism Industry. Ministry of Tourism.)

Stages of development strategies for culinary tourism destinations:

1. Destination Determination

2. Mapping 3A including identification of the Tourist Market. 


\section{Designing Activities}

4. Documentation

5. Promotion.

Efforts are made, namely: complete accessibility to culinary tourism destinations by adding amenities. Furthermore, the culinary tourism activities such as cooking classes, workshops related to culinary, night market for culinary are expected to increase tourist visits to Vietnam.

\subsection{Communication Strategy in Promoting Cultural Tourism Desti- nations in Semarang City}

The culinary industry has great potential in Indonesia to continue to develop and maximize consistency in the Indonesian culinary industry into several aspects, namely aspects of $\mathrm{HR}$ development, capital aspects, intellectual property aspects, infrastructure aspects and marketing aspects, among others, through city branding.

In order to discuss the Communication Strategy in Promoting the Cultural Tourism Destinations of the City of Semarang, the following frameworks are needed:

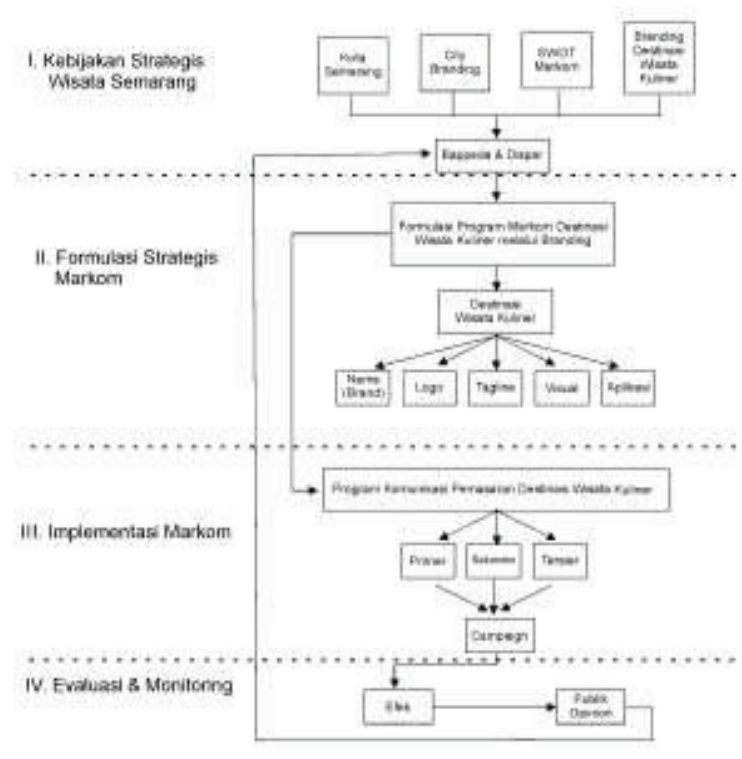

Figure 5: Rerangka Berpikir, Sumber : diolah peneliti

Information :

The strategy of determining Semarang City as a Culinary tourist destination as City Branding Semarang. 
1. Situation Analysis Strategy (SSA) includes external and internal analysis (SWOT), establishing Policy, Vision, Mission.

2. The Formulation (SF) strategy includes the Semarang Tourism Office Marketing Communication Program in the form of City Branding. Logo, Tagline, and determination of Semarang tourist destination activities as Culinary tourist Destinations and city branding communication programs based on strategy formulations.

3. Implementation Strategy (SI) includes campaign programs, campaign schedules and costs.

4. The Evaluation and Monitoring Strategy (SE\& M) includes the Monitoring and Evaluation of the Campaign Program

Based on the picture of the above framework, it can be explained that 1) Situation Strategy Analysis (SSA) includes external and internal factors that can be seen as SWOT which establishes Semarang City Government program policies, including Vision / policy. (Marhanani, 2018)

Then primary communication comes from the government, in this case the Semarang city government, yang kemudian dijalankan oleh Badan Perencanaan Daerah (Bappeda) dan Dinas Pariwisata (Diparda). Komunikasi primer tersebut berlanjut dengan komunikasi sekunder, yakni melalui perancangan program komunikasi, yakni upaya membuat rancangan pelaksanaan kegiatan komunikasi, dalam hal ini adalah city branding Kota Semarang, mulai dari perencanaan, pengorganisasian, pelaksanaan di lapangan hingga monitoring dan evaluasi (monev) kegiatan komunikasi tersebut berdasarkan Strategi Formulasi (SF).

Penyusunan program komunikasi tersebut di implementasikan dalam rangka mengkampanyekan, mensosialisasikan, atau mempromosikan produk, yakni city branding kepada khalayak sasaran tertentu atau kepada masyarakat luas berdasarkan Strategi Implentation (SI). Agar segala sesuatu berjalan dengan baik dan mencapai tujuan yang diinginkan maka disusun perencanaan komunikasinya, seperti apa produknya, siapa khalayak sasarannya, apa tujuannya, apa strateginya, apa pesannya, apa salurannya, dan siapa komunikatornya.

Penyusunan program komunikasi tersier ini Dinas Pariwiata Semarang melibatkan Dinas Komunikasi dan Informasi Kota Semarang serta konsultan komunikasi (PR dan periklanan). Tujuan kampanye komunikasi ini memiliki jangkauan pendek maupun jangka panjang (short and long-term planning), mengakar ke bawah (bottom up), berorientasi pada kepentingan penerima (audience oriented) dan bermaksud mencapai tujuan akhir yang besar (ultimate purpose). 
Untuk komunikasi tersier, hal ini melibatkan kampanye komunikasi word of mouth, yang bertujuan agar city branding dari Kota Semarang sebagai destinasi wisata Kuliner tersebut melalui komunikasi interpersonal dari orang ke orang. Komunikasi tersier juga melibatkan opini publik dalam pembentukan opini mengenai city branding kota Semarang. Selanjutnya monitoring dan evaluasi program kampanye (campaign) yang telah dilaksanakan berdasarkan Strategi Evaluasi Monitoring (SEM).

Kota Semarang memiliki potensi sebagai kota pendidikan, kota jasa, dan kota wisata. Namun, terkait dengan dengan penulisan disertasi ini, potensi yang akan digali lebih mendalam adalah Kota Semarang sebagai destinasi wisata, baik itu destinasi wisata alam maupun destinasi wisata Kuliner.

Pariwisata merupakan salah satu faktor penting dalam perkembangan perekonomian di Kota Semarang. Kota Semarang sebagai salah satu kota tujuan wisata yang memiliki beberapa jenis wisata yaitu wisata alam, wisata sejarah, wisata budaya, wisata minat khusus, wisata kuliner, wisata religi, wisata Kuliner. hal ini merupakan suatu daya tarik para wisatawan mancanegara dan domestik untuk melakukan kunjungan ke Kota Semarang.

\section{Destinasi wisata Kuliner}

Kota Semarang yang asri dan nyaman ditambah kekayaan seni budaya dan kreatifitas masyarakat Semarang dalam bidang mode membuat kota ini mendapatkan julukan Surganya Kuliner.

Semarang yang terkenal dengan pelopor wisata kuliner, membuat kota ini kaya dengan berbagai nama makanan yang khas (Tahu Pong, Wingko Babat, Bandeng Presto, dll). Jika ingin merasakan wisata kuliner di kota ini, untuk mencicipi makanan khas dapat mengunjungi restoran, cafe, rumah makan yang mempunyai brand terkenal yang akhir-akhir ini sudah mulai menjamur.

Kementerian Pariwisata menetapkan makanan khas daerah meliputi (1) Soto (2) Rendang (3) Sate (4) Nasi Goreng (5) Gado-gado. Upaya tersebut dilakukan kementerian pariwisata dalam rangka mempromosikan restoran Indonesia yang berada di luar negeri. Hal ini memungkinkan untuk membranding restoran yang sudah ada di luar negeri. Dalam hal ini terdapat 10 restoran di seluruh dunia yang akan dibranding oleh Wonderful Indonesia seperti beberapa restoran di Eropa dan Amerika. Selanjutnya Indonesia melakukan strategi diplomasi tentang kuliner Indonesia.

Kementerian Pariwisata akan memberikan Insentif berupa promosi insentif bentuk restoran seperti 10 restoran yang sudah menandatangani insentif sebagai co-branding yang digunakan berupa promosi melalui media dan endoser. 
Target diharapkan 100 restoran yang dipromosikan untuk co branding Wonderful Indonesia. Dalam hal ini perlu juga diperhatikan mempromosikan restoran dengan standarisasi rasa makanan yang akan dijual baik restoran di dalam negeri maupun di luar negeri.

Jumlah restoran di Semarang saat ini kurang lebih 38 restoran yang menjual makanan khas Semarang seperti lumpia, bandeng presto, dll (kompas.com).

Dalam kajian ini menggunakan metodologis, dengan paradigma konstruktivitis, dengan pendekatan interpretif. Paradigma yang mendasari munculnya fenomena mengenai city branding adalah adanya pemikiran yang konstruktivis. Konstruktivisme merupakan suatu pendekatan yang lazim digunakan dalam studi ilmu komunikasi. Konstruktivisme memberi tekanan pada dampak perbedaan individu yang tetap, dalam proses-proses persepsi sosial atas pengembangan perilaku komunikasi. Selain itu juga menggunakan perilaku komunikasi yang berpusat pada manusia. Paradigma ini memiliki tujuan untuk melakukan rekonstruksi pemahaman. Pengetahuan yang diperoleh berupa rekonstruksi pemikiran individual yang menyatu dengan lingkungan sosialnya. Nilai-nilai diperlakukan menyatu dalam proses kajian, yakni dibentuk bersama dalam interaksi antara peneliti dan yang diteliti.

Pemikiran konstruktivis terjadi akibat adanya interaksi yang terjadi antara peneliti dengan sistem atau subjek kajian yang dalam hal ini adalah sebuah kota mencakup pemerintahan, destinasi pariwisata, wisatawan Kuliner, para pemangku kepentingan pariwisata, juga diperkuat dengan bagaimana pesan-pesan yang dimunculkan untuk membawa sebuah tujuan yang berbentuk visi misi atau yang sekarang ini kita tekankan on the formation of a city branding of a city. Constructivism paradigm is understanding data subjectively something that is personal expectations and desires of the parties being studied. The constructive paradigm involves the values and beliefs of the subject. In this case the researcher is a "passionate participant" as well as a facilitator that bridges the diversity of subjectivity of tourist actors. In addition, this study needs to be able to reflect on the social reality dictically between the researcher and the one being studied.

Data / information collection techniques and data understanding are triangulative. Interview with Culinary tourism stakeholders. Direct observation of culinary tourism carried out by tourists (perceptions, awareness, expectations, and their loyalty) in the city of Semarang to find out how the identity affects and is influenced by the social life of the Semarang community and its influence in the tourism development of the city of Semarang.

Secondary data was obtained from the official website of the Semarang Regional Government, the official website of the Semarang Regional Tourism Office, reports on 
economic growth from Bank Indonesia, the Semarang Regional Statistics Agency report, Semarang history and cultural books, marketing magazines and Tourism magazines.

\subsection{Communication Strategy in Promoting Cultural Tourism Des- tinations in Semarang City.}

In order to identify Semarang city culinary tourism destinations with city branding, efforts that need to be carried out include knowing the position of strengths and weaknesses and the opportunities and challenges of Culinary tourism destinations in Semarang City, SWOT analysis is needed as follows:

The results of the SWOT analysis above revealed the SO strategy and WO strategy.

The SO (Strength Opportunity) strategy is as follows.

- Strengthen the identity of Semarang city Culinary tourism destinations with city branding.

- Strategic Semarang locations are visited by many tourists

- Need to Strengthen Semarang as a Culinary Tourism Destination

Likewise for the Weakness Opportunity (WO) strategy includes:

- Semarang City is densely populated

- Jalan Kota Semarang sometimes gets stuck

- Strengthen the identity of Semarang City Culinary Destination

- Many visited by tourists and tourists (Malaysia, Singapore and the Middle East)

- Improve tourism infrastructure in Semarang

- Furthermore, the WT (Weak \& Thread) strategy, among others, the City of Semarang has competitors with

The stipulation of other destinations as a contribution to the main market of Nusantara tourism, for example East Java. Therefore strengthening the identity of the Semarang city Culinary tourism destination with city branding is needed by the coordination of all Government stakeholders, the tourism industry, academics, the media and the people of Semarang City. (source: Marhanani Tri Astuti, 2017)

The use of logos and branding from the center, "Joglosemar" is in line with the Decree of the Minister of Tourism of the Republic of Indonesia No. KM.38 / UM.001 / MP / 2017 about Branding Logo 10 Indonesian Tourism Destinations. The Semarang branding logo is presented in the following picture 10: 
TABLE 2: SWOT ANALISIS (Sumber : diolah oleh peneliti)

\begin{tabular}{|c|c|c|}
\hline External & $\begin{array}{l}\text { STRENGTH } \\
\text { Identity of Semarang } \\
\text { City Culinary } \\
\text { Destination with } \\
\text { City Branding } \\
\\
\text { The location of } \\
\text { Semarang is } \\
\text { strategic because it } \\
\text { is located between } \\
\text { Central Java and DI } \\
\text { Yogyakarta. }\end{array}$ & $\begin{array}{l}\text { WEAKNESS } \\
\text { Semarang city is } \\
\text { densely populated } \\
\text { Semarang City } \\
\text { Road sometimes } \\
\text { gets stuck } \\
\text { Not yet the identity } \\
\text { of Semarang city } \\
\text { Culinary tourism } \\
\text { destination with } \\
\text { city Branding }\end{array}$ \\
\hline $\begin{array}{l}\text { OPPORTUNITIES } \\
\text { Strengthen the } \\
\text { identity of Semarang } \\
\text { City Culinary } \\
\text { Destinations } \\
\text { Many visited by } \\
\text { tourists and tourists } \\
\text { (Malaysia, Singapore } \\
\text { and Middle East) }\end{array}$ & $\begin{array}{l}\text { SO Strategy } \\
\text { Strengthen the } \\
\text { identity of Semarang } \\
\text { city culinary } \\
\text { destinations with } \\
\text { city branding. } \\
\text { Strategic Semarang } \\
\text { locations are visited } \\
\text { by many tourists. } \\
\text { Strengthening } \\
\text { Semarang needs to } \\
\text { be a Culinary } \\
\text { Tourism Destination }\end{array}$ & $\begin{array}{l}\text { WO Strategy } \\
\text { Semarang city is } \\
\text { densely populated } \\
\text { Semarang City } \\
\text { Road sometimes } \\
\text { gets stuck. } \\
\text { Strengthen the } \\
\text { identity of } \\
\text { Semarang City } \\
\text { Culinary } \\
\text { Destinations }\end{array}$ \\
\hline
\end{tabular}

\begin{tabular}{|c|c|c|}
\hline & & Semarang. \\
\hline $\begin{array}{l}\text { THREATS } \\
\text { Semarang has } \\
\text { competitors with its } \\
\text { stipulations, other } \\
\text { destinations as the } \\
\text { main market } \\
\text { contribution of } \\
\text { domestic tourists such } \\
\text { as East Java. } \\
\text { Semarang as the } \\
\text { City of Culinary } \\
\text { Travel Destinations }\end{array}$ & $\begin{array}{l}\text { ST Strategy } \\
\text { Strengthen the } \\
\text { identity of } \\
\text { Semarang City } \\
\text { Culinary } \\
\text { Destination as a } \\
\text { Culinary Tourism } \\
\text { Destination } \\
\text { The location of } \\
\text { Semarang is } \\
\text { strategic because it } \\
\text { is located between } \\
\text { Central Java and DI } \\
\text { Yogyakarta } \\
\text { The city of } \\
\text { Semarang has } \\
\text { competitors with } \\
\text { the determination of } \\
\text { other destinations as } \\
\text { a contribution to the } \\
\text { main tourism } \\
\text { market of the } \\
\text { archipelago such as } \\
\text { East Java. } \\
\text { Strengthening } \\
\text { the identity of } \\
\text { Semarang City } \\
\text { Culinary } \\
\text { Destination with } \\
\text { Semarang city } \\
\text { branding as } \\
\text { Culinary tourism }\end{array}$ & $\begin{array}{l}\text { WT Strategy } \\
\text { Semarang city is } \\
\text { densely populated } \\
\text { Semarang City } \\
\text { Road sometimes } \\
\text { gets stuck } \\
\text { There is no } \\
\text { Branding in } \\
\text { Semarang City } \\
\text { The city of } \\
\text { Semarang has } \\
\text { competitors with } \\
\text { the determination } \\
\text { of other } \\
\text { destinations as the } \\
\text { main market } \\
\text { contribution of } \\
\text { tourists such as } \\
\text { East Java. } \\
\text { Strengthening the } \\
\text { identity of } \\
\text { Semarang's } \\
\text { Culinary Travel } \\
\text { Destinations with } \\
\text { City Branding } \\
\text { Semarang }\end{array}$ \\
\hline
\end{tabular}

The Branding of Semarang City as a City. 


\section{java}

Figure 6: Logo branding "Joglosemar"

Figure 7: Semarang Variety of Culture branding logo

Source: https://twitter.com/YogyakartaCity

In strengthening the visit of Semarang City tourists, it should pay attention to the desire of the community to bring up the culinary tourism destination of Semarang City as branding. The desire of the people that emerged and strengthened the identity of the culinary tourist destinations of the city of Semarang.

The decision of the Minister of Tourism explained that Joglosemar's branding logo was "Java Cultural Wonders" explaining Semarang which is rich in history, culture, art, and culinary, and its natural beauty.

From the aspect of marketing Semarang, the slogan "Variety of Culture" was made so that marketing was in line with "Wonderful Indonesia" as the main concept of national tourism marketing. Later, wherever "Wonderful Indonesia" appears, "Variety of Culture" will also be promoted.

In the end, building a branding strategy involving the city community in it cannot be the task of one organization. All stakeholders need to involve the City Government, Business Actors, Media, Local Universities, Cultural Institutions and heritage, tourism actors, community leaders. The involvement of all stakeholders will ensure a diverse perspective and map the entire city problem so that it will make the implementation of the branding process a little lighter. 


\subsection{Communication Strategy in Promoting Cultural Tourism Des- tinations in Semarang City}

It became a challenge for the City of Semarang to show itself to the outside world. How can the brand that is built get a place in the hearts of the people, both the people of Semarang City and other regional communities. In addition, how to strengthen the brand identity of the brand with the policies and products produced by the city of Semarang is a task that involves many stakeholders, namely the local government (in this case Semarang City Tourism Office, restaurant owners, academics / campus, community local and media.

Efforts to strengthen the identity of the Semarang City Culinary Destination with City Branding are not only limited to carrying out various events, but more than that. Because branding is closely related to imaging and product positioning in the minds of the public as consumers, the brand made has value. Branding is a process of strengthening the identity of Culinary Travel Destinations with City Branding. In this case, maturity is needed in planning until the brand has its own position in the minds of consumers.

The communication strategy used by the Semarang City Government more specifically refers to the marketing communication strategy. This can be seen from the background of brand compilation activities is to market their regions in increasing tourism competitiveness.

This brand recognition is included in one of the brand awareness levels. To achieve brand awareness, effective and consistent marketing communication is needed. The Semarang City Government makes various programs related to brands to introduce the brand to the public. Each communication program that is run has its own objectives. Although these programs have the same main goal, namely introducing a brand or raising awareness of the brand while strengthening the identity of Semarang city tourist destinations with city branding

By using a strategic communication approach (Kavaratzis.2004) and reinforced by Anholt's (2009) city branding model, the communication strategy in question is the Integrated Stakeholder Communication (ISC) model which is a synergy of primary communication, secondary communication and tertiary communication.

Primary communication is in the form of government policy (government / regulator) in disseminating and facilitating infrastructure and tourism access, urban planning, Culinary tourism zone policies and public areas. At this level of primary communication the government (in this case the tourism office) has a role as the initiator of city branding and digital marketing. Socializing Minister of Tourism Decree no. 38/2017 about the 
National tourism branding logo. Providing digital access to tourist destinations, building supporting infrastructure. Provide online support data: Culinary tourism deregulation; shopping tax refund; duty free shop; shoping street; Culinary products; annual culinary events etc.

Secondary communication is communication carried out by stakeholders, in this case business people as enablers, local communities as accelerators, academics as a conceptor in the framework of city branding. Business people as enablers have a role to play in strengthening the use of E-Commerce company websites: Provision of Online Booking services, Joining Travel Exchange (Buy and Sell). Accelerate Digital Lifestyle creates positive ambience about culinary destinations in the digital world.

At the level of tertiary communication, communication is related to interaction between layers of society and is reinforced by the media as a catalyst. Tertiary communication is a container or media that involves stakeholders from the public, private and community dimensions in a systematic and sustainable manner. In tertiary communication an agreement will be made to share the roles and functions of stakeholders in accordance with the principles: synergy, empowerment of stakeholders, synchronization, harmonization, collaboration / cooperation, efficiency, and strengthening the effectiveness of city branding activities. Tertiary communication is also an interface that mobilizes stakeholders in strengthening and accelerating the development of city branding. Tertiary communication is a medium of moderation, facilitation and mediation activities for stakeholders in the context of developing city branding. Also as a medium of dialogue, discussion, identification of issues and program socialization that are relevant to the development of city branding.

In line with the city branding, Kartajaya (2005) argues that currently the regional government needs to morph into a customer-oriented local government and is responsible for all stakeholders equally. In terms of regional economic management and development through tourism, for example, local governments also need to shift from a bureaucratic approach to a strategic entrepreneurial approach. This approach requires three basic elements in regional planning, namely the establishment of regional long-term vision and goals, efforts to build entrepreneurial culture in regional human resources and the formulation of solid regional strategies. This regional strategy is called Kartajaya with the Strategic Place Triangle, which includes positioning, developing differentiation and building regional brands.

In an effort to implement the brand in detail the branding strategy that connects strategy and tactics and between consumers and products. This strategy includes Positioning $(P)$, in terms of the nature (strategy) and focus (consumer) Differentiation (D), 
including the nature (tactics) and focus (product) and Branding (B) including the nature (value / reputation) and focus (perception / image). Branding is part of promotion, namely branding consists of awareness, interest and advertising include desire and selling is action.

\subsection{Semarang As A City Of Culinary Tourism Destinations}

The city of Semarang is famous as a Culinary Destination for the Simpang Lima Region, Culinary Area JI. Pemuda, Taman Siswa Bauran Area, Culinary Area Jl. Sriwijaya, Culinary Area Jl. Ahmad Yani.

The number of culinary areas supports the development of the tourism sector in the city of Semarang. Furthermore, according to UN-WTO: 2014 Culinary is part of human activities, which includes behavior, use or utilization of available resources, and raises interactions with other human groups, with economic elements, and the environment faced. In accordance with the statement, Semarang has long been a Culinary tourist destination.

1. Strategic Communication

(a) Primary Communication

Primary communication is held by the Semarang City Culture and Tourism Office, Semarang Tourism Official, and is supported by the tourism industry, academics, the media and the community.

In promoting the branding of Semarang City, the Semarang Tourism Office uses twitter social media to share information with all levels of society.

Furthermore, building a communication strategy through branding strategies involving the city community in it cannot be the task of one organization. All stakeholders need to be involved, including the City Government, Business Actors, Media, Local Universities, Cultural Institutions and heritage, tourism actors, community leaders and others. The involvement of all stakeholders can guarantee a diverse perspective to address the city's problems.

(b) Secondary Communication

Activity of Semarang City Culture and Tourism Office in marketing Semarang City Branding.

From the aspect of marketing Semarang, the slogan "Variety of Culture" was made so that marketing was in line with "Wonderful Indonesia" as the main 
concept of national tourism marketing. Later, wherever "Wonderful Indonesia" appears, "Variety of Culture" will also be promoted.

(c) Tertiary Communication

Community Response to Semarang City Branding As a Culinary Tourism Destination. Likewise the media response to the Branding of Semarang City.

Although the branding of Semarang City was agreed upon as a Variety of Culture, there was a contestation between the parties who had an interest in the Semarang brand, to promote Semarang City as a tourist destination.

Implementation of Strategic Communication

Efforts made by the Semarang City Government to strengthen the identity of the Semarang City Culinary Destination with City Branding:

1. Primary Communication

Landscape strategies are related to actions in areas of action and decisions that are appropriate for urban design, architecture, green zones, and public areas in the city

A number of steps were taken by the Semarang City Government to establish a Culinary tourist destination. Among other things is the addition of culinary facilities in several locations in the city of Semarang. Furthermore, increasing infrastructure includes adding parking spaces for visitors to culinary tourism locations.

\section{Secondary Communication}

Practical marketing activities such as indoor and outdoor advertising, public relations, graphic design, use of logos.

A number of steps were taken by the Semarang City Government to strengthen the identity of the Semarang City Culinary Destination with City Branding, among others by creating a website www.Semarang.go.id.

The Regional Government carries out the following activities:

(a) Education to the community, namely conscious tourism socialization in the form of Sapta Pesona action activities, among others, inviting the public to participate in cleaning tourist attractions.

(b) Promotion, among others, the Government includes the tourism industry in tourism exhibitions at home and abroad.

(c) Creating an event calendar The government accommodates events carried out by the community in the annual event calendar 
(d) Supervision and evaluation of programs implemented by the Semarang City Government.

\section{Tertiary Communication}

Include the public and the media to communicate and promote culinary tourism destinations in the City of Semarang through City Branding.

\section{Conclusion}

Communication strategy in promoting culinary tourism destinations can be through City branding of Semarang City, by placing the position of Semarang City as a Culinary tourism destination.

The role of the Office of Culture and Tourism tends to accept policies and programs from the central government: "that the branding of the city of Semarang needs to be related to the creativity of the city, while the majority of people accept the branding of Semarang as a Culinary tourist destination".

The regional government morphed into a customer-oriented local government and is responsible for all stakeholders equally.

The development of Semarang city branding into a Culinary tourist destination is the direction and responsibility.

The step of developing the Semarang City brand as a Culinary tourism destination refers to efforts to promote and strengthen and coordinate between stakeholders as the main strength of Semarang as a Culinary tourism destination in Semarang city branding program

City branding can be seen as a communication policy, because it is carried out by the government and with regard to public affairs. The communication strategy used by the Semarang City Government more specifically refers to the marketing communication strategy.

City branding communication involves three aspects of communication, namely primary communication, secondary communication and tertiary communication.

Semarang City branding primary communication involves the Semarang City Culture and Tourism Office, Semarang Tourism Official, and is supported by academics, researchers, the tourism industry.

Secondary communication is related to the efforts and policies taken by the Semarang City Culture and Tourism Office in marketing city branding. 
Tertiary communication consists of the community response to the branding of Semarang City as a Culinary tourist destination, the media's response to the branding of the City of Semarang, and the efforts made by the Semarang City Cultural and Tourism Office to obtain media coverage and expectations for the news.

\section{References}

[1] Aaker, D. A. (1991). Managing Brand Equity: Capitalizing on the Value of a Brand Name. New York: Free Press.

[2] Anholt, S. (2009). Competitive Identity: The New Brand Management for Nations, Cities and Regions. Berlin:Springer

[3] Ashworth, G. J and Voogd, H. (1990). Selling the City: Marketing Approaches in Public Sector Urban Planning. Belhaven Press, London

[4] Bakhtiar, A. (2004). Filsafat Ilmu. Jakarta: Raja Grafindo Persada.

[5] Braun, E. (2008). City Marketing; Towars an Integrated Approach. Rotterdam: Desertasi Erasmus University.

[6] CEOs for Cities. (2006) Artikel; Branding Your City. London: Prophet.

[7] Copley, P. (2004) Marketing Communications Management - Concepts and Theories. London: Elsevier Butterworth-Heinemann

[8] Cova, B. and Badot, O. (1995). Marketing Theory and Practice in a Postmodern Era. Baker, M.J. Marketing

[9] T. Duncan, (2005). Theory and Practice. Basingstoke: Macmillan.

[10] Durianto, S. and Budiman, (2004). Brand Equty TOT; Strategi Memimpin Pasar. Jakarta: Gramedia Pustaka Utama.

[11] Engel, J. F. (2001). Consumer Behavior Millenium Edition. New Jersey: Prentice Hall.

[12] Hermawan, A, (2005). Kajian Bisnis Paradigma Kuantitatif. Jakarta: PT Grasindo.

[13] Estawara, (2008). Think IMC. Jakarta: Gramedia Pustaka Utama

[14] Gregory, R. J. and Wiechmann, G. J. (2002). Marketing Corporate Image; The Company as Your Number One Product, NTC Business Books. Illinois USA: Lincoln Word.

[15] Hankinson, G. and Cowking P. (1995). What do you really mean by the brand? The Journal of Brand Management, vol. 3 issue 1, pp. 43-50.

[16] Inn, K. (2004). Plan for City Identity Establishment and City Marketing: The Cases of Kimpo City. vol 21. Issue 1, pp. 233-240 
[17] Jefkins, F. (1994). Public Relations Techniques. Butterworth Heinemann, Public Relations (Edisi Keempat). Jakarta: Erlangga.

[18] Karimah, K. E. and Wahyudin, U. F. dan Etika K. (2010). Aspek Ontologis, Epistemologis, dan Aksiologis Dalam Memandang IImu Komunikasi. Widya Padjadjaran, Bandung.

[19] Kartajaya, H. 2005. Attracting Tourist Traders Investors: Strategi Memasarkan Daerah di Era Otonomi. Jakarta: Gramedia Pustaka Utama

[20] Kasali, R. (1994). Manajemen public relations: konsep dan aplikasinya di Indonesia. Jakarta: Grafiti Medika Pers.

[21] Kavaratzis, M. (2004). From City Marketing To City Branding. Henry Stewart Publications, vol. 1, issue 1, pp. 58-73.

[22] Keller, K. L. (2006). Strategic Brand Management; Building, Measuring and Managing Brand Equity. New Jersey: Prentice Hall.

[23] Kennedy, J. E. and Dermawan S. R. (2006). Marketing Communication -Taktik dan Strategi. Jakarta: PT Buana IImu Populer.

[24] Knapp, D. E. (2001). The Brand Mindset. Yogyakarta: Penerbit Yayasan Andi.

[25] Kotler, P. dan Amstrong, G. (2004). Dasar - Dasar Pemasaran Edisi Kesembilan Jilid Dua. Jakarta: PT Gramedia.

[26] Kotler, P. (2005). Manejemen Pemasaran. (2004). Jakarta: PT Erlangga

[27] Kotler, P. (2005). Marketing Insights from A to Z. Jakarta: PT Erlangga.

[28] Kotler, P. dan Waldemar, P. (2006). B2B Brand Management. Jakarta: PT Bhuana IImu Populer.

[29] Littlejohn, S. W. and Karen A. F. (2008). Theories of Human Communication. Illinois: Waveland Press.

[30] Marhanani, T. A. (2017). Disertasi Memperkuat Identitas Destinasi Wisata Belanja Kota Bandung Dengan City Branding. Jakarta: Universitas Sahid.

[31] Marhanani, T. A. (2018). Memperkuat Identitas Destinasi Wisata Kuliner. Yogyakarta: Keppel Press.

[32] Morissan, (2007). Periklanan :Komunikasi Pemasaran. Jakarta: Kencana Prenada.

[33] Moore, F. (2004). Humas Membangun Citra dengan Komunikasi. Bandung: PT Remaja Rosdakarya.

[34] Schultz, D. E. (2003). The Next Generation of Integrated. International Journal of Advertising, vol. 24, issue 1, pp. 7-34.

[35] Schultz, D. E. (2003). Marketing Communication. Interactive Marketing, vol. 4, issue 4, pp. 318-319. 
[36] Shimp, T. A. (2000). Periklanaii Promosi; Aspek Tambahan Komunikasi Pemasaran Terbaru. Jakarta: Penerbit Erlangga.

[37] Simon, A. (2007). How The World Views Its Cities. 3rd Edition. New York: Palgrave Macmillan.

[38] Tomlinson, J. (2003). Globalization and Cultural Identity, The global transformations reader. Cambrige: Blackwell Pub.

[39] Vermeulen, M. (2002). City Branding, Image Building and Building Images. Rotterdam: NAI Publishers.

[40] Bella, A. (2017). Ini Makna 10 Branding Baru Destinasi Wisata Indonesia. Retrieved 6, 16, 2019 from http://marketeers.com/ini-makna-di-balik-10-branding-baru-destinasiwisata-indonesia. 